\title{
Wykorzystanie zasobów krajobrazowych w polityce przestrzennej gmin na obszarze aglomeracji poznańskiej - między strategią a praktyką
}

\section{Use of landscape resources in the municipal spatial policy in the Poznań agglomeration - between strategy and practice}

\author{
Agnieszka WILKANIEC ${ }^{1} \bullet E_{z l}$ bieta RASZEJA² $\bullet$ Magdalena SZCZEPAŃSKA $^{3}$ \\ ${ }^{1}$ Uniwersytet Przyrodniczy w Poznaniu \\ Katedra Terenów Zieleni i Architektury Krajobrazu \\ ul. Dąbrowskiego 159, 60-594 Poznań \\ ktzagawi@up.poznan.pl \\ ${ }^{2}$ Uniwersytet Artystyczny w Poznaniu \\ Wydział Architektury i Wzornictwa, Katedra Architektury i Urbanistyki \\ Aleje Marcinkowskiego 29, 60-967 Poznań \\ elzbieta.raszeja@wokiss.pl \\ ${ }^{3}$ Uniwersytet im. Adama Mickiewicza w Poznaniu \\ Instytut Geografii Społeczno-Ekonomicznej i Gospodarki Przestrzennej \\ ul. B. Krygowskiego 10, 61-680 Poznań \\ szmagda@amu.edu.pl
}

Zarys treści: Zasoby przyrodnicze i krajobrazowe mogą stanowić istotną podstawę rozwoju gmin wiejskich. Intensywna urbanizacja terenów podmiejskich powoduje, że są one narażone na znacznie szybszą utratę tych zasobów niż jednostki położone peryferyjnie w stosunku do aglomeracji miejskich. Tym ważniejsza wydaje się w tym kontekście identyfikacja istniejących walorów w gminach podmiejskich, a także ich ochrona z wykorzystaniem narzędzi planistycznych. Celem prezentowanych badań jest rozpoznanie sposobu wykorzystania zasobów krajobrazowych w gminach aglomeracji poznańskiej oraz konfrontacja praktyki gospodarowania przestrzenią z zapisami w studiach gmin. Posłużono się przykładem trzech gmin - Dopiewo, Tarnowo Podgórne i Stęszew - położonych w zachodniej części powiatu poznańskiego w paśmie intensywnego rozwoju osadnictwa podmiejskiego. Wskazano cenne zasoby przyrodnicze i krajobrazowe, ze szczególnym uwzględnieniem terenów leśnych i zbiorników wodnych. Przeprowadzono badania dotyczące dynamiki zmian użytkowania przestrzeni będącej w bezpośrednim sąsiedztwie tych terenów, opisywanych w dokumentach planistycznych gmin jako najcenniejsze z punktu widzenia występujących zasobów. Zaobserwowano wyraźne różnice w sposobie prowadzenia polityki przestrzennej poszczególnych gmin w kontekście zachowania posiadanych zasobów.

Słowa kluczowe: zasoby przestrzenne, walory przyrodnicze, krajobraz kulturowy, gminy podmiejskie, aglomeracja poznańska. 


\section{Wprowadzenie}

Kreowanie strategii rozwojowych obszarów wiejskich na bazie zasobów lokalnych postrzegane jest jako szansa na budowanie stabilnych systemów ekonomicznych i aktywizację społeczną oraz racjonalne wykorzystanie posiadanego potencjału. Realizacja tej idei może przybierać różne formy, co wynika zarówno z rozmaitości zasobów, jak i zróżnicowania typologicznego obszarów wiejskich. Położenie, rodzaj i intensywność powiązań zewnętrznych, poziom i kierunki rozwoju, uwarunkowania przyrodnicze i kulturowe, relacje społeczne - to najważniejsze czynniki różnicujące te obszary. Na tym tle szczególna jest sytuacja wsi podmiejskich, określanych zgodnie z typologią OECD jako obszary ekonomicznie zintegrowane, których rozwój ekonomiczny i demograficzny jest bezpośrednio związany z bliskością dynamicznie rozwijających się dużych ośrodków miejskich, przy czym rodzaj i intensywność tych związków zmienia się wraz z odległością od granic miasta (Bański 2008). System powiązań miast z obszarami otaczającymi jest coraz bardziej złożony i wielowymiarowy, zaś współczesne procesy cywilizacyjne tworzą wciąż nowe wzajemne zależności. Z jednej strony mamy do czynienia z ofertą ośrodka miejskiego dla terenów podmiejskich w postaci szerokiego zakresu wysokiej jakości usług oraz miejsc pracy, z drugiej - skierowaną z obszarów wiejskich do miasta ofertą w postaci terenów pod nowe inwestycje (mieszkaniowe, produkcyjne, infrastrukturalne, komunikacyjne), coraz częściej ostatnio wskazywanych usług ekosystemowych (zapewnienie równowagi ekologicznej, korzystanie z zasobów naturalnych) czy też zaplecza rekreacyjnego (Raszeja 2013). Strategie rozwoju obszarów wiejskich uznają zwykle sąsiedztwo aglomeracji miejskich za czynnik sprzyjający rozwojowi ekonomicznemu i aktywizujący wieś oraz realne źródło dochodów. Tymczasem w praktyce system relacji miasta z jego wiejskim otoczeniem często funkcjonuje na zasadzie „centrum-peryferie”, a więc wbrew zasadom wzajemnego dopełniania i wzajemnie korzystnego współistnienia, a obszary wiejskie stają się „zapasowymi terenami” dla rozwoju miast (Raszeja 2006). Prowadzone badania wskazują, że coraz silniejsza presja urbanizacyjna na tereny wiejskie powoduje nie tylko istotne zmiany w strukturze własnościowej i użytkowaniu gruntów (Świderski 2007; Głębocki 2008), ale też zagrożenia dla wartościowych zasobów przyrodniczych i krajobrazowych oraz nieodwracalne przekształcenia historycznego rozplanowania wsi (Raszeja 2008; Staszewska 2012; Wójcik 2013; Szczepańska i Wilkaniec 2014).

Poszukiwanie prawidłowych strategii rozwojowych dla obszarów wiejskich w otoczeniu dużych miast wymaga dostrzeżenia specyfiki lokalnych zasobów poszczególnych jednostek wiejskich, ale jednocześnie ujęć systemowych i spojrzenia z perspektywy całego złożonego układu osadniczego. Przykładem takiego podejścia jest koncepcja partnerstwa miasto-wieś, odpowiadająca na pytanie, jak tworzyć nowe relacje, aby realizować ideę rozwoju zrównoważonego oraz wskazująca nową politykę terytorialną i nowe podejście do planowania przestrzennego na zasadzie obopólnych korzyści (Baranowski 2002; Halamska 2006). Cennym doświadczeniem w zakresie kreowania spójnej polityki rozwojowej oraz właściwego wykorzystania potencjału obszarów wiejskich w relacjach z dużym miastem jest realizowany w latach 2009-2010 interdyscyplinarny program badawczy „Funkcjonowanie i kierunki rozwoju aglomeracji poznańskiej”, a w jego ramach temat „Krajobraz i dziedzictwo kulturowe wsi w aglomeracji poznańskiej”. Rezultatem było stworzenie koncepcji polityki krajobrazowej, opartej na identyfikacji i zachowaniu zasobów krajobrazowych jako potencjału rozwojowego obszarów wiejskich w obrębie aglomeracji. 
Polityka krajobrazowa wpisywała się w podstawowe założenia strategiczne rozwoju aglomeracji poznańskiej, to jest spójność i konkurencyjność. Jako warunek spójności uznano integrację społeczną i gospodarczą opartą na identyfikacji przestrzenno-krajobrazowej i wzmacnianiu tożsamości kulturowej mieszkańców, natomiast specyfika i wyjątkowość przestrzeni przyrodniczej i historyczno-kulturowej została wskazana jako potencjał dla budowania konkurencyjności. Jednym z najważniejszych zadań strategicznych sformułowanych w ramach polityki krajobrazowej było stworzenie zintegrowanego systemu ochrony krajobrazu w planowaniu i zarządzaniu przestrzenią. Taki system miały tworzyć odpowiednie zapisy w studiach gmin i planach miejscowych, proces prognozowania i oceny wpływu projektowanych inwestycji na krajobraz, a także prowadzenie monitoringu krajobrazu, pozwalającego na rejestrację jego stanu oraz ocenę dynamiki i charakteru zmian (Raszeja i in. 2010). Włączenie polityki krajobrazowej do strategii rozwoju aglomeracji było szansą na wprowadzenie jej w życie jako integralnej części całościowego programu, realizowanego poprzez wzajemnie powiązane działania w różnych sektorach. Założenia polityki krajobrazowej zostały przedstawione do szerokich konsultacji społecznych jako jeden z rozdziałów dokumentu roboczego - tzw. „zielonej księgi”, a następnie przyjęte przez Radę Aglomeracji Poznańskiej i opublikowane w dokumencie Strategia rozwoju aglomeracji poznańskiej (2011), czyli tzw. „białej księdze”. Kilka lat po opublikowaniu strategii warto przyjrzeć się, jak gminy podmiejskie sąsiadujące z Poznaniem realizują jej założenia i jak wykorzystują swój potencjał przestrzenny i krajobrazowy. W tym kontekście rodzą się następujące pytania: Czy opracowanie strategiczne dla aglomeracji zmieniło podejście do metod identyfikacji zasobów krajobrazowych w gminach? Czy gminy właściwie wykorzystują ten potencjał? Jaką rolę pełnią w tym zakresie instrumenty planistyczne? Czy w polityce rozwojowej gmin jest realizowana zasada spójności i konkurencyjności?

Celem badań przeprowadzonych przez autorki było rozpoznanie sposobu wykorzystania zasobów krajobrazowych w wybranych gminach aglomeracji poznańskiej oraz konfrontacja odnoszących się do tego zapisów zawartych w studiach gmin z praktyką gospodarowania przestrzenią. W pierwszym etapie badań zidentyfikowano zasoby przyrodnicze i krajobrazowe, ze szczególnym uwzględnieniem terenów leśnych i zbiorników wodnych, opisywanych w dokumentach planistycznych gmin jako najcenniejsze zasoby i potencjał rozwoju. Następnie przeprowadzono badania dotyczące dynamiki zmian użytkowania przestrzeni będącej w bezpośrednim sąsiedztwie tych terenów oraz wpływu analizowanych zmian na jakość i trwałość zasobów.

\section{Obszar, materiał i metody badań}

Wybrane do badań gminy: Dopiewo, Tarnowo Podgórne i Stęszew, z terenu których zaczerpnięto przykłady ilustrujące podjętą problematykę, położone są w powiecie poznańskim, w zachodniej i południowo-zachodniej jego części (ryc. 1). Na ich terenie następuje szybki rozwój zabudowy mieszkaniowej, w związku z bliskością Poznania i dostępnością komunikacyjną, związaną z przebiegiem autostrady i dróg krajowych. Dotyczy to zwłaszcza gmin Dopiewo i Tarnowo Podgórne, w mniejszym stopniu gminy Stęszew. Na analizowanym terenie występują różne formy obszarowej ochrony przyrody: w gminie Stęszew Wielkopolski Park Narodowy i tereny Natura 2000, na terenie gmin Dopiewo i Tarnowo Podgórne obszary ochrony powołane przez samorządy gminne, tj. Obszar Chronionego 
Krajobrazu Jeziora Niepruszewskiego (Dopiewo), Obszar Chronionego Krajobrazu Rynny Jeziora Lusowskiego i Doliny Samy (Tarnowo Podgórne). Do istotnych walorów przyrodniczych, nieobjętych formami ochrony można zaliczyć na tym terenie doliny cieków i zbiorników wodnych oraz duże powierzchniowo kompleksy leśne. Wszystkie badane gminy posiadają znaczne walory dziedzictwa kulturowego: wartościowe fragmenty krajobrazu rolniczego, cenne układy przestrzenne związane z historycznymi wsiami i zespołami rezydencjonalno-folwarcznymi, zabytkowe i historyczne obiekty i zespoły zabudowy, a także założenia komponowanej zieleni.

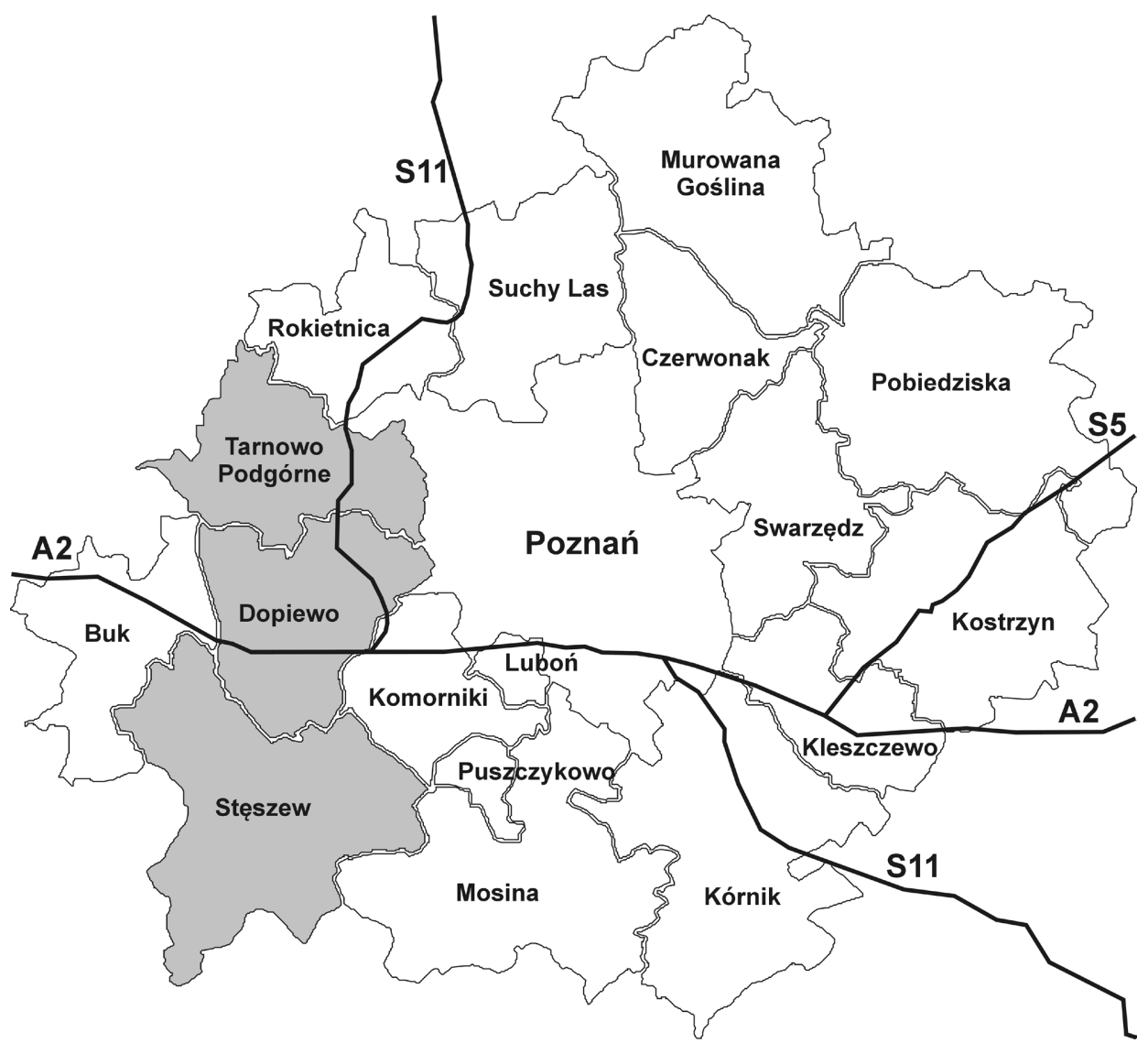

Ryc. 1. Lokalizacja gmin objętych badaniami na tle powiatu poznańskiego i układu głównych dróg Źródło: opracowanie własne.

Location of communes covered by the research in the Poznan county and along the main roads Source: own study.

W ramach prowadzonych badań przeanalizowano studia uwarunkowań i kierunków zagospodarowania przestrzennego (suikzp) dla wybranych trzech gmin, jako dokumenty prezentujące politykę przestrzenną kształtowaną przez organy samorządowe. Zwrócono szczególną uwagę na to, jak reprezentowane są zagadnienia związane z zasobami krajobrazu kulturowego, a także, jakie efekty przynosi polityka przestrzenna realizowana przez gminy w odniesieniu do konkretnych, wybranych elementów. Badaniami objęto położone 
w granicach gmin Dopiewo i Tarnowo Podgórne tereny leśne i otoczenie jezior, uznane w analizowanych dokumentach obu gmin za cenne zasoby. Przeanalizowano dynamikę zmian przestrzennych przebiegających na terenie kompleksu leśnego, tzw. lasów zakrzewskich i w jego otoczeniu oraz w sąsiedztwie Jeziora Lusowskiego. Badany teren leśny położony jest na terenie obu gmin, zaś jezioro na terenie gminy Tarnowo Podgórne. Wokół obu obiektów wyznaczono strefę otaczającą ich granice pasem szerokości jednego kilometra (wzięto pod uwagę aktualne granice lasu oraz linię brzegową jeziora) i w oparciu o materiały kartograficzne przeanalizowano zmiany powierzchni lasu i zabudowy na tym terenie w trzech przekrojach czasowych: lata 40. XX w. (Messtichbtatt... 1940-44)), koniec lat 70. XX w. (Mapa topograficzna... 1979) i okres współczesny (Ortofotomapa... 2014). Taki dobór przekrojów czasowych miał służyć ukazaniu sytuacji przestrzennej na analizowanym terenie w ujęciu historycznym, przed przemianami społeczno-gospodarczymi, politycznymi i prawnymi z początku lat 90. XX w. oraz współcześnie. Oprócz powierzchni lasu, jeziora i zabudowy w wyznaczonej strefie zmierzono również długość granicy lasu i linii brzegowej jeziora oraz linii styku zabudowy z granicą lasu i linią brzegową jeziora. Pomiarów wszystkich objętych badaniami parametrów dokonano na podstawie rysunków zawartych w studiach dla obu gmin. Pomiary wykonano w programie ArcGIS 10.1, do analiz współczesnego stanu użytkowania terenów wykorzystano zdjęcia lotnicze dostępne online w bibliotekach programu (Ortofotomapa... 2014). Wyniki pomiarów przedstawiono w tabelach 1 i 2.

\section{Postrzeganie i wizja wykorzystania zasobów w polityce przestrzennej gmin}

\section{Gmina Dopiewo}

Dwa pierwsze cele strategiczne, które wymieniono w studium uwarunkowań i kierunków zagospodarowania przestrzennego w części odnoszącej się do kierunków, to „osiągnięcie zrównoważonego rozwoju” oraz „zachowanie i podniesienie walorów istniejącego środowiska kulturowego" (Gmina Dopiewo..., t. Kierunki, 2013, s. 5). W części dotyczącej uwarunkowań stwierdza się, że „środowisko przyrodnicze jest jednym z głównych, jeśli nie najważniejszym czynnikiem, warunkującym rozwój gminy” i przyjmuje założenie, że konstrukcja studium „polega na sprecyzowaniu barier chroniących najcenniejsze wartości środowiska, na kompromisowym dopuszczeniu zagospodarowania na obszarach bardziej odpornych na degradację, spowodowaną procesami antropogenicznymi oraz na wskazaniu terenów, na których wszelkiego rodzaju działalność inwestycyjna może swobodnie rozwijać się" (Gmina Dopiewo..., t. Uwarunkowania, 2013, s. 37). Dokument precyzuje, że „głównymi barierami dla rozwoju funkcji mieszkaniowej i funkcji gospodarczych (z wyjątkiem rolnictwa i leśnictwa) " są między innymi: fragment Wielkopolskiego Parku Narodowego (WPN), obszary lasów, doliny cieków wodnych, itp. Jako zasób pozwalający rozwijać funkcje rekreacyjne postrzegane jest Jezioro Niepruszewskie (tamże, 38). Konsekwentnie w części studium odnoszącej się do kierunków zagospodarowania przestrzennego widoczne jest ujmowanie zasobów przyrodniczych i krajobrazowych dwubiegunowo: jako barier (konieczność ochrony najcenniejszych fragmentów terenu, skutkująca niemożnością wprowadzenia zabudowy) lub czynnika stymulującego rozwój zabudowy rekreacyjnej i rezydencjalnej w miejscach szczególnie atrakcyjnych oraz innego rodzaju na pozostałym obszarze gminy (Gmina Dopiewo..., t. Kierunki, 2013, s. 6). 
Zasoby dziedzictwa kulturowego zdaniem autorów tego dokumentu to istotny element struktury funkcjonalno-przestrzennej gminy. Słusznie zwrócono uwagę na brak studium ruralistycznego dla gminy oraz innych opracowań dotyczących środowiska kulturowego (Gmina Dopiewo..., t. Uwarunkowania, 2013, s. 39, 42). W punkcie odnoszącym się do uwarunkowań wynikających z ochrony wartości kulturowych stwierdzono, że Dopiewo nie należy do gmin o bogatym środowisku kulturowym (utożsamianym z krajobrazem kulturowym), dlatego trzeba w szczególny sposób dbać o utrzymanie i właściwe wyeksponowanie tych zasobów. Dalej zwraca się uwagę na dwojakiego rodzaju skutki takiego potraktowania dóbr kultury: z jednej strony daje to szansę na rozwój turystyczny gminy, z drugiej stanowi barierę w jej rozwoju z powodu ograniczeń inwestycyjnych. W tekście umieszczono również spostrzeżenie, że największe znaczenie dla rozwoju gminy mają tereny atrakcyjne krajobrazowo, uzasadniając, że na ich podstawie można rozwijać funkcje rekreacyjne i tworzyć zespoły zabudowy rezydencjonalnej (tamże, s. 42). Cytowany fragment dokumentu zawiera również stwierdzenie, że istnienie zabytków stwarza pewne problemy zarówno dla ich właścicieli czy użytkowników, jak i dla samorządu gminnego, związane z wymaganiami dotyczącymi zagospodarowania na cele użytkowe zabytku nieruchomego (tamże, s. 43). Wyżej wymienione sformułowania świadczą o przekonaniu, że istniejące zasoby kulturowe są cenne, o ile można je wykorzystać i dzięki temu osiągnąć wymierne korzyści. Natomiast jeśli nie dają takich możliwości, mogą być postrzegane również jako problem. Zapisy dokumentu świadczą też o tym, że intensywny rozwój zabudowy nie jest postrzegany jako potencjalne zagrożenie dla walorów dziedzictwa kulturowego.

W sferze kształtowania polityki przestrzennej można odnieść wrażenie, że studium zakłada bierne poddawanie się istniejącym trendom. W części opracowania odnoszącej się do uwarunkowań wynikających z dotychczasowego zainwestowania zawarte są słuszne wnioski dotyczące negatywnych zjawisk, związanych z rozwojem przestrzennym poszczególnych wsi, takich jak „obrastanie historycznych układów” przez nową zabudowę czy „rozciągnięcie wsi wzdłuż dróg”, a jednocześnie sankcjonuje się dalsze utrwalanie tych tendencji, uzasadniając istniejącym już rozproszeniem zabudowy oraz wykorzystaniem pokrywającego się z drogami przebiegu uzbrojenia terenu. W tym samym punkcie odnotowano potrzebę podążania za dotychczasowymi trendami widocznymi w zagospodarowaniu przestrzennym. Stwierdzono, że „szereg podziałów geodezyjnych gruntów rolnych na działki o znamionach działek budowlanych, szczególnie we wschodniej i północnej części gminy oraz zakup tych gruntów przez ludność nie tylko z obszaru gminy Dopiewo, wskazuje na konieczność przeznaczenia tych terenów pod zabudowę mieszkaniową" (tamże, s. 58). Rozwój gminy uzależnia się przede wszystkim od usytuowania na jej terenie zabudowy mieszkaniowej powstającej na potrzeby osób pracujących w Poznaniu i obrębie obszaru metropolitalnego" oraz terenów związanych z aktywizacją gospodarczą, usytuowanych wzdłuż głównych tras komunikacyjnych (tamże, s. 60). Gmina postrzega swoje szanse rozwoju głównie w wykorzystaniu bliskiego sąsiedztwa miasta i korzystnych uwarunkowań komunikacyjnych (tamże, s. 62). Niechęć do przeciwstawiania się spontanicznie kształtującym się tendencjom rozwojowym wyrażona została w części dotyczącej kierunków w sposób następujący: „chodzi o to, by nie przekreślać dotychczasowego sposobu użytkowania terenów, a jedynie skorygować kierunki rozwoju, usprawnić je, wzbogacić" (Gmina Dopiewo..., t. Kierunki, 2013, s. 5). W związku z tym w obowiązującym studium (2013) przewiduje się na terenie gminy możliwość znacznego powiększenia się powierzchni terenów zabudowanych, głównie o funkcji mieszkaniowej oraz produkcyjno-magazy- 
nowej. Tereny przeznaczone potencjalnie pod zabudowę produkcyjno-magazynową koncentrują się wzdłuż przebiegu autostrady (również w dość dużej odległości od węzłów drogowych) oraz istniejących i projektowanych dróg szybkiego ruchu (S11, S5). Nowe tereny zabudowy mieszkaniowej oraz usługowej usytuowane zostały wokół istniejących wsi, i wzdłuż dróg w sposób powodujący zacieranie się granic pomiędzy poszczególnymi jednostkami osadniczymi, co stanowi bezpośrednie zagrożenie dla krajobrazu rolniczego. Tereny przeznaczone pod zabudowę dotykają bezpośrednio granic kompleksów leśnych w tym wchodzących w skład WPN i obszaru Natura 2000 w rejonie miejscowości Lisówki.

\section{Gmina Tarnowo Podgórne}

W studium uwarunkowań i kierunków zagospodarowania przestrzennego (2011) jako najcenniejsze zasoby środowiska przyrodniczego wymieniono: Jezioro Lusowskie, dolinę rzeki Samy, tereny leśne, aleje drzew, cenne zbiorowiska roślinne (m.in. wodne, nadwodne, leśne), teren dawnej Wojewódzkiej Szkółki Zadrzewieniowej (północna strona drogi Lusowo-Lusówko), teren dawnego użytku ekologicznego w Chybach. W dokumencie, w części odnoszącej się do uwarunkowań, zwraca się uwagę na możliwość rozwijania różnych form turystyki i rekreacji w oparciu o zasoby środowiska przyrodniczego, walory krajobrazowe oraz takie elementy dziedzictwa kulturowego, jak parki dworskie (Tarnowo Podgórne..., cz. A, 2011, s. 65). Zasoby dziedzictwa kulturowego zgodnie z zapisami Studium obejmują obiekty i zespoły zabytkowe oraz budownictwo wiejskie charakterystyczne dla osadnictwa olęderskiego jako element kultury regionalnej, a także przydrożne krzyże i kapliczki jako wyróżniki krajobrazowe (tamże, s. 46).

Sformułowania zawarte w części odnoszącej się do kierunków wydają się wskazywać na chęć równoważenia rozwoju przestrzennego i zachowania oraz właściwego wykorzystania istniejących zasobów, o czym świadczy m.in. niniejsza deklaracja: „Właściwe kreowanie polityki przestrzennej powinno polegać nie tylko na tworzeniu nowych obszarów inwestycyjnych, ale również na ochronie środowiska oraz poprawie standardów terenów już zabudowanych" (Tarnowo Podgórne..., cz. B, 2011, s. 88). Dowodem na podejmowanie przez gminę działań w tym kierunku jest utworzenie Obszaru Chronionego Krajobrazu Rynny Jeziora Lusowskiego i Doliny Samy. Walory środowiska przyrodniczego wskazywane są jako aktywizujące czynniki wewnętrzne, umożliwiające rozwój gminy (tamże, s. 3). Wśród działań na rzecz rozwoju gminy wymienia się: zmniejszanie stopnia zanieczyszczenia środowiska przyrodniczego, zwiększanie lesistości gminy, zrównoważone przeznaczanie terenów pod zabudowę, kształtowanie systemu zieleni. W części studium odnoszącej się do zasad ochrony środowiska i jego zasobów, ochrony przyrody i krajobrazu kulturowego zawarto dość szczegółowe zalecenia dotyczące poszczególnych terenów, komponentów środowiska przyrodniczego oraz krajobrazu. Wśród interesujących i ważnych zapisów można wymienić ustalenia dotyczące: objęcia ochroną zadrzewień cmentarzy, parków, alei przydrożnych (z wymienieniem konkretnych obiektów), zalecenie podkreślania istniejących w krajobrazie rolniczym walorów widokowych, inwentaryzacji istniejącego drzewostanu parków i zadrzewień towarzyszących drogom (tamże, s. 34). W części dokumentu dotyczącej kierunków i zasad kształtowania rolniczej przestrzeni produkcyjnej i obszarów leśnych zawarto m.in. zalecenia dotyczące dążenia do ochrony krajobrazu rolniczego, wprowadzono zakaz zabudowy na części terenów rolniczej przestrzeni produkcyjnej i zalecenie zwiększenia lesistości terenu. W zbiorze zasad ochrony dziedzictwa kulturowego 
i zabytków oraz dóbr kultury współczesnej zawarto zalecenia dotyczące m.in.: utrzymania właściwego stanu zabytkowych obiektów oraz ich otoczenia, zasad wprowadzania nowej zabudowy w ich sąsiedztwie, ustanowiono strefy ochrony konserwatorskiej dla zespołów historycznej zabudowy (dworskich i pałacowych, parkowych, folwarcznych), wprowadzono zakaz wznoszenia nowej zabudowy i dokonywania wtórnych podziałów parków historycznych (tamże, s. 41).

Omawiane studium dla gminy Tarnowo Podgórne zakłada możliwość znaczącego powiększenia powierzchni zabudowy, szczególnie związanej z działalnością gospodarczą, wzdłuż drogi E30 i w Wysogotowie oraz mieszkaniowej, koncentrującej się głównie w pobliżu Tarnowa Podgórnego, Lusowa, Lusówka, Chyb i Sierosławia. Wśród innych istotnych zmian rysunek Studium wskazuje duże powierzchniowo tereny przeznaczone na zalesienia, pomiędzy drogą łączącą Poznań z Bukiem a jeziorem Lusowskim oraz tereny usług turystyki i wypoczynku nad jeziorem Lusowskim, na jego północnym brzegu, pozbawione prawa zabudowy, bezpośrednio stykające się z brzegiem jeziora oraz z ograniczonym prawem wprowadzania obiektów kubaturowych na południowym brzegu jeziora oraz wzdłuż drogi łączącej Lusowo i Lusówko.

\section{Gmina Stęszew}

W obowiązującym studium uwarunkowań i kierunków zagospodarowania przestrzennego (2014) mocno podkreślane jest występowanie na terenie gminy wybitnych walorów przyrodniczych i potrzeba ich ochrony, przy czym jako cenny zasób postrzegane są jeziora. W dokumencie znajdują się również zapisy wskazujące na krajobraz kulturowy jako walor. Wśród zasad kształtowania polityki przestrzennej wymienia się: racjonalne zagospodarowanie terenów i ograniczenie rozpraszania zabudowy, wykorzystanie dogodnego położenia gminy i jej walorów przyrodniczych w aktywizacji funkcji turystycznej, ochronę potencjału przyrodniczego, ochronę zwartych kompleksów leśnych korytarza ekologicznego sieci ECONET, ochronę walorów krajobrazowych oraz kulturowych poprzez wprowadzenie odpowiednich ograniczeń w zagospodarowaniu i wykorzystaniu terenów (Studium... 2014, s. 98)

Wśród kierunków rozwoju gminy na pierwszym miejscu wymieniana jest ochrona i zachowanie walorów przyrodniczych (tamże, s. 99), podczas gdy na drugim miejscu rozwój funkcji mieszkaniowej, co może powodować powstawanie konfliktów przestrzennych, o ile te cele nie będą realizowane w odrębnych przestrzeniach. Kolejne wymienione kierunki: rozwój infrastruktury sportowo-rekreacyjnej, turystycznej i utrzymanie funkcji rolniczej oraz rozwój przetwórstwa rolno-spożywczego, związane są z wykorzystaniem istniejących walorów środowiska i wynikają z dotychczasowej struktury użytkowania terenów. W studium podkreśla się, że w części wschodniej gminy, objętej obszarowymi formami ochrony przyrody: „dominujące powinny być działania związane z celami ochrony parku narodowego oraz obszarów Natura 2000. Na tym terenie należy utrzymywać ciągłość korytarzy ekologicznych, minimalizować kolizje człowiek-środowisko, utrzymywać a nawet zwiększać lesistość, promować rolnictwo ekologiczne”, natomiast w części południowej gminy „dążyć do zachowania krajobrazu kulturowego i dziedzictwa kulturowego wsi, będącego zapisem dziejów kolejnych pokoleń i ich relacji ze środowiskiem” (tamże, s. 99). W części północno-zachodniej gminy, gdzie znajduje się Jezioro Strykowskie za podstawowy kierunek rozwoju uznaje się rekreację i turystykę. Niepokojący jest zapis dotyczący utrzymania 
funkcji rolniczej w kontekście „prowadzenia na terenie gminy intensywnego rolnictwa wysokotowarowego" (tamże, s. 99). Ważne w odniesieniu do zachowania walorów krajobrazu rolniczego jest zalecenie dotyczące „koncentracji zabudowy wsi poprzez lokalizowanie nowych inwestycji wokół istniejących siedlisk” i „ograniczenie wydawania rozpraszających zabudowę decyzji o warunkach zabudowy" (tamże, s. 100). Podkreślona została również rola wyłączeń spod zabudowy jako narzędzia kształtującego jakość krajobrazu. Jako wyłączone spod zabudowy wskazane zostały: tereny rolne i zieleni nieurządzonej (w szczególności znajdujące się w „zasięgu strefy cennej przyrodniczo predysponowanej do objęcia nowymi formami ochrony przyrody", wyznaczonych na północny zachód od Jeziora Tomickiego na terenach uznanych za niezwykle cenne przyrodniczo i krajobrazowo) oraz lasów (tamże, s. 110). Zagadnienia związane z ochroną dziedzictwa kulturowego postrzegane są głównie przez pryzmat ochrony poszczególnych historycznych i zabytkowych obiektów oraz ich otoczenia. W zakresie ochrony większych zespołów przestrzennych, takich jak układy urbanistyczne i ruralistyczne, studium odwołuje się do zapisów w Planie zagospodarowania przestrzennego województwa wielkopolskiego, którego zapisy mają bardzo ogólny charakter ze względu na skalę i zakres opracowania tego dokumentu (tamże, s. 120). W części graficznej studium zawiera oznaczenie „cennych układów ruralistycznych" występujących w kilku wsiach oraz objęty ochroną konserwatorską układ urbanistyczny Stęszewa.

W porównaniu ze studium gmin Tarnowo Podgórne i Dopiewo opracowanie planistyczne dla Stęszewa zakłada najmniejsze powiększenie powierzchni terenów zabudowanych. Przewiduje się możliwość pojawienia się dużego kompleksu zabudowy produkcyjno-magazynowej (w okolicy Strykowa), zabudowy mieszkaniowej i usługowej, przylegającej bezpośrednio do granicy lasu (w Sapowicach, Skrzynkach i Trzebawiu) oraz zabudowy usytuowanej wzdłuż dróg (w Modrzu, Wronczynie, Będlewie i Łodzi), co powoduje zlewanie się zabudowy poszczególnych wsi. Pojawienie się wskazanych w studium pojedynczych niewielkich kompleksów zabudowy izolowanych od historycznych układów przestrzennych wsi (w Tomicach, i okolicach Stęszewa), spowoduje rozpraszanie zabudowy. Powyższe zapisy prawdopodobnie sankcjonują wydane już decyzje o warunkach zabudowy i zagospodarowania przestrzennego. Za bardzo korzystne ze względu na ochronę krajobrazu należy uznać przeznaczenie znacznej powierzchni gminy na tereny rolnicze, wyłączone z zabudowy, a także wyznaczenie przebiegu lokalnych korytarzy ekologicznych oraz wspomnianej już strefy cennej przyrodniczo, predysponowanej do objęcia nowymi formami ochrony przyrody

\section{Przekształcenia użytkowania terenów jako zagrożenie walorów krajobrazowych w gminach Dopiewo i Tarnowo Podgórne}

Z deklaracji zawartych w studiach dla badanych gmin wynika, że walory przyrodnicze obiekty i zespoły zabytkowe stanowią zasób, który samorządy gminne chciałyby wykorzystać w celu rozwoju gmin. Rzadziej jako walor bądź zasób wymieniany jest krajobraz kulturowy, choć i on pojawia się w tym kontekście we wszystkich analizowanych dokumentach. Przytoczone poniżej przykłady dotyczące terenu opisywanych gmin pokazują, jak w praktyce władze samorządowe odnoszą się do posiadanych zasobów. Analiza dynamiki zmian przestrzennych dotykających kompleksu leśnego lasów zakrzewskich oraz 
Jeziora Lusowskiego wraz z otoczeniem przyniosła interesujące wyniki. Oba te obszary zostały uznane w dokumentach planistycznych za cenne, co było powodem konfrontacji deklaracji zawartych w studiach gmin z ich praktyką gospodarowania przestrzenią na tych obszarach. Zmiany w użytkowaniu terenów otaczających kompleks lasów zakrzewskich i Jeziora Lusowskiego, dotyczące głównie powiększania się powierzchni zabudowy (wraz z ogrodami działkowymi i terenami rekreacyjno-sportowymi na których dopuszczalne jest sytuowanie zabudowy) w odległości 1 km od granicy lasu i linii brzegowej jeziora, w kolejnych przekrojach czasowych oraz możliwości rozwoju zabudowy wg studiów gmin Tarnowo Podgórne i Dopiewo przedstawiono na rycinach 2 i 3. Dokonano pomiarów zachodzących zmian użytkowania: zmiany powierzchni terenów zabudowanych w otoczeniu kompleksu leśnego i jeziora, długości linii granicznej kompleksu lasów i linii brzegowej jeziora oraz linii stycznej lasu i zabudowy i brzegu jeziora i zabudowy. Wyniki pomiarów przedstawiono w tabelach 1 i 2.

Przeprowadzone analizy wskazują, że powierzchnia lasów na terenie obu gmin znacznie wzrosła od lat 40. XX w., szczególnie na terenie gminy Tarnowo Podgórne, gdzie w ramach polityki prowadzonej przez władze samorządowe zakłada się kontynuację dolesień (tab. 1). Mimo zawartych w studium gminy Dopiewo deklaracji, że „specjalnego potraktowania wymaga obrzeże lasów" jako strefy przejściowej ochrony siedliskowej lasu oraz że „wskazane jest kanalizowanie ruchu rekreantów po lesie i wytyczenie wejść do niego zielenią wysoką i krzewiastą, by uniknąć wejść w miejscach niepożądanych" (Gmina Dopiewo..., t. Kierunki, s. 21), powierzchnia kompleksów zabudowy stykającej się bezpośrednio z granicą lasu stale się powiększa, a studium gminy Dopiewo zakłada kontynuację tego trendu (tab. 1, 2). Może to doprowadzić do otoczenia kompleksu leśnego zwartym pasmem zabudowy ze wszystkich stron, z pozostawieniem fragmentu styku pól uprawnych i lasu jedynie od strony zachodniej (ryc. 2; tab. 2). Realizacja takiego scenariusza rozwoju przestrzennego z pewnością nie wpłynie pozytywnie na stan obrzeża lasu, znacznie zwiększy penetrację terenu przez ludzi oraz przerwie jakiekolwiek powiązania ekologiczne istniejące pomiędzy lasem a terenami położonymi na zachód i południe od niego, ograniczone już teraz przez budowę drogi szybkiego ruchu S11. Nie wydaje się, aby przewidywane zmiany o tak dużym zasięgu mogły zostać znacząco złagodzone dzięki wyznaczeniu pasów określonych w studium jako „tereny zainwestowane, wymagające specyficznego zagospodarowania z uwagi na sąsiedztwo z lasem", których rozmieszczenie wskazuje rysunek studium, nie precyzując jednak, jakiego rodzaju działania miałyby zostać w tym przypadku podjęte. W gminie Tarnowo Podgórne powierzchnia zabudowy na terenach otaczających las również wzrosła w bardzo znaczący sposób, ale nie są planowane tak wielkie zmiany w przyszłości (ryc. 3, tab. 1, 2). Co prawda na rysunku studium gminy Tarnowo Podgórne widoczne jest wydłużenie linii styku zabudowy z lasem, jednak nie wynika to z wyznaczania nowych terenów pod zabudowę przy granicy istniejącego lasu (jak ma to miejsce w przypadku Dopiewa), lecz związane jest z przewidzianymi dolesieniami.

Stwierdzenie zawarte w studium gminy Tarnowo Podgórne, że „koniecznym warunkiem ochrony wód Jeziora Lusowskiego jest wyeliminowanie rozwoju zabudowy i potencjalnych zagrożeń z nią związanych na terenach przyległych bezpośrednio do rynny jeziornej" (Tarnowo Podgórne..., cz. A, 2011, s. 28) ma znaczenie wyłącznie deklaratywne, a nie realne, ponieważ studium przewiduje możliwość zarówno powiększenia się powierzchni zabudowy w strefie sąsiadującej bezpośrednio z jeziorem, jak i wydłużenie linii styku zabudowy z brzegiem jeziora (ryc. 3; tab. 1, 2) 
Tabela 1. Zestawienie powierzchni kompleksu lasów zakrzewskich i Jeziora Lusowskiego oraz zabudowy w ich otoczeniu, na terenie gmin Dopiewo i Tarnowo Podgórne

\begin{tabular}{|c|c|c|c|c|c|}
\hline \multirow{2}{*}{$\begin{array}{c}\text { Forma użytkowania } \\
\text { terenu }\end{array}$} & \multirow[b]{2}{*}{ Gmina } & \multicolumn{4}{|c|}{ Powierzchnia [ha] } \\
\hline & & lata 40. XX w. & $\begin{array}{c}\text { koniec lat } 70 . \\
\text { XX w. }\end{array}$ & współcześnie & suikzp \\
\hline \multirow{3}{*}{ Las } & Dopiewo & 916,1 & 1217,1 & 1187,4 & 1169,8 \\
\hline & $\begin{array}{l}\text { Tarnowo } \\
\text { Podgórne }\end{array}$ & 103,7 & 312,0 & 359,5 & 539,9 \\
\hline & Sumarycznie & 1019,8 & 1529,1 & 1546,9 & 1709,7 \\
\hline \multirow{3}{*}{$\begin{array}{l}\text { Zabudowa w strefie } \\
\text { przyleśnej }\end{array}$} & Dopiewo & $\begin{array}{l}24,5 \\
(0,0)\end{array}$ & $\begin{array}{l}53,3 \\
(0,0)\end{array}$ & $\begin{array}{l}320,9 \\
(51,2)\end{array}$ & $\begin{array}{r}1135,8 \\
(87,6)\end{array}$ \\
\hline & $\begin{array}{l}\text { Tarnowo } \\
\text { Podgórne }\end{array}$ & $\begin{array}{r}21 \\
(0,0)\end{array}$ & $\begin{array}{l}26,5 \\
(4,3)\end{array}$ & $\begin{array}{l}205,9 \\
(92,6)\end{array}$ & $\begin{array}{l}331,1 \\
(87,5)\end{array}$ \\
\hline & Sumarycznie & 45,5 & 79,8 & 526,8 & 1466,9 \\
\hline Jezioro & $\begin{array}{l}\text { Tarnowo } \\
\text { Podgórne }\end{array}$ & 125,4 & 125,4 & 125,4 & 125,4 \\
\hline $\begin{array}{l}\text { Zabudowa w strefie } \\
\text { przyjeziornej }\end{array}$ & $\begin{array}{l}\text { Tarnowo } \\
\text { Podgórne }\end{array}$ & $\begin{array}{l}23,3 \\
(0,0)\end{array}$ & $\begin{array}{l}44,1 \\
(3,9)\end{array}$ & $\begin{array}{l}105,2 \\
(26,4)\end{array}$ & $\begin{array}{l}252,8 \\
(35,2)\end{array}$ \\
\hline
\end{tabular}

W nawiasach podano powierzchnię terenów ogrodów działkowych, działek rekreacyjnych i przeznaczonych pod usługi sportowe.

Źródło: opracowanie własne na podstawie: Messtichblatt (1940-44), Mapa topograficzna (1979), Ortofotomapa, Gmina Dopiewo... (2013), Tarnowo Podgórne... (2011).

Tabela 2. Długość linii granicznej kompleksu lasów zakrzewskich i linii brzegowej Jeziora Lusowskiego oraz linii stycznej lasu i zabudowy i brzegu jeziora i zabudowy

\begin{tabular}{|c|c|c|c|c|c|}
\hline \multirow{2}{*}{$\begin{array}{c}\text { Forma użytkowania } \\
\text { terenu }\end{array}$} & \multirow[b]{2}{*}{ Gmina } & \multicolumn{4}{|c|}{ Długość [km] } \\
\hline & & lata 40. XX w. & $\begin{array}{c}\text { koniec lat } 70 . \\
\text { XX w. }\end{array}$ & współcześnie & suikzp \\
\hline \multirow{3}{*}{ Linia graniczna lasu } & Dopiewo & 26,3 & 41,8 & 44,6 & 39,0 \\
\hline & Tarnowo Podgórne & 12,4 & 24,9 & 21,6 & 29,6 \\
\hline & Sumarycznie & 38,7 & 66,8 & 66,4 & 68,6 \\
\hline \multirow{3}{*}{$\begin{array}{l}\text { Linia stycznej lasu } \\
\text { i zabudowy }\end{array}$} & Dopiewo & 0,0 & 1,6 & 8,9 & 22,0 \\
\hline & Tarnowo Podgórne & 0,0 & 0,0 & 6,2 & $8,4^{*}$ \\
\hline & Sumarycznie & 0,0 & 1,6 & 15,8 & 30,4 \\
\hline $\begin{array}{l}\text { Linia brzegowej } \\
\text { jeziora }\end{array}$ & Tarnowo Podgórne & 8,6 & 8,6 & 8,6 & 8,6 \\
\hline $\begin{array}{l}\text { Linia stycznej brzegu } \\
\text { jeziora i zabudowy }\end{array}$ & Tarnowo Podgórne & 0,5 & 0,9 & 1,4 & 2,6 \\
\hline
\end{tabular}

*brano pod uwagę linię styku zabudowy z istniejącym kompleksem leśnym (nie z planowanymi kompleksami dolesień).

Źródło: opracowanie własne na podstawie Messtichblatt (1940-44), Mapa topograficzna (1979), Ortofotomapa, Gmina Dopiewo... (2013), Tarnowo Podgórne... (2011). 

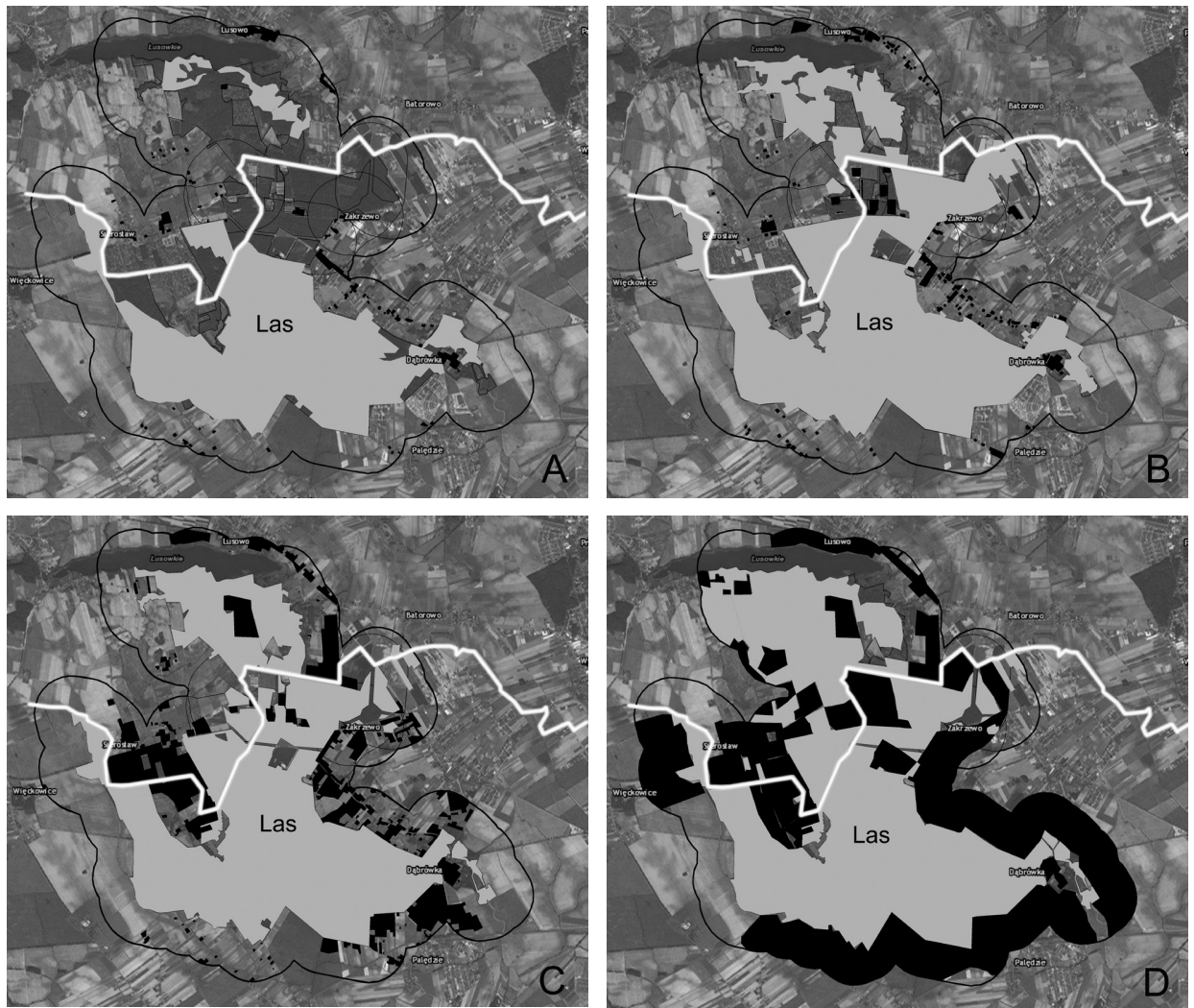

Ryc. 2. Zmiany w użytkowaniu terenów otaczających kompleks lasów zakrzewskich.

Kolory: jasnoszary - powierzchnia lasu, czarny - powierzchnia zabudowy (wraz z ogrodami działkowymi i terenami rekreacyjno-sportowymi, na których dopuszczalne jest sytuowanie zabudowy). Linie: czarna - granica strefy obejmującej teren w odległości $1 \mathrm{~km}$ od linii brzegowej lasu, biała - granica gmin Dopiewo i Tarnowo Podgórne. Kolejne mapy pokazują sytuację: A - w latach 40. XX w.; B - pod koniec lat 70. XX w.; C - współcześnie; D - możliwości rozwoju zabudowy wg: Gmina Dopiewo... 2013, Tarnowo Podgórne... 2011. Źródło: opracowanie własne na podstawie: Messtichblatt (1940-44), Mapa topograficzna (1979), Ortofotomapa, Gmina Dopiewo... (2013), Tarnowo Podgórne... (2011).

Changes in land use in surroundings of the forest complex (Lasy Zakrzewskie). Colours: light grey - forest area; black - building area (with allotment gardens and sports and leisure areas where buildings are allowed to be constructed). Lines: black - border zone comprising the area of $1 \mathrm{~km}$ of forest boundary; white - the border of Dopiewo and Tarnowo Podgórne communes. Subsequent maps show the situation: $A$-in the 1940s; B-in the late 1970s; C - today; D - potential development of building areas according to spatial planning documents of the Tarnowo Podgórne and Dopiewo communes.

Source: own study based on Messtichblatt (1940-44), Mapa topograficzna (1979), Ortofotomapa, Gmina Dopiewo... (2013), Tarnowo Podgórne... (2011). 

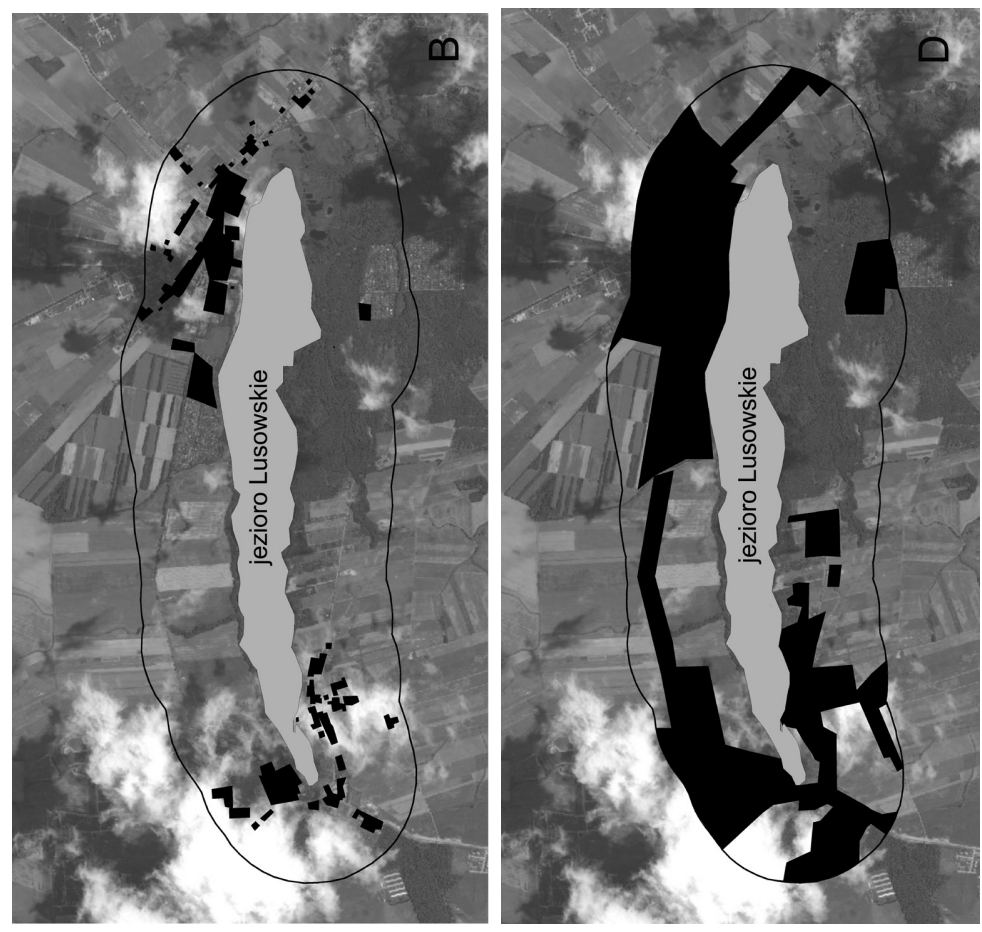

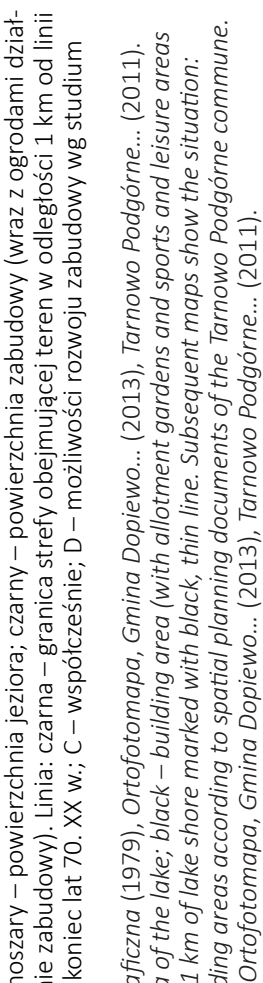
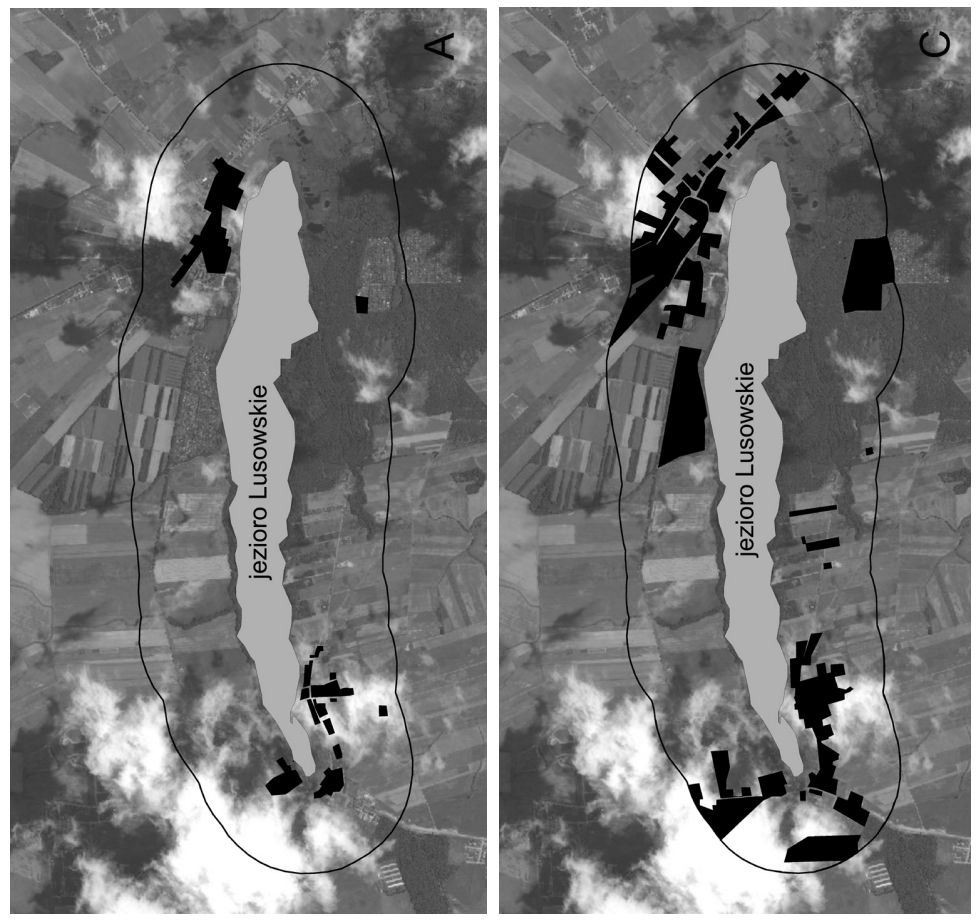

出.

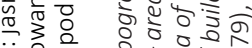

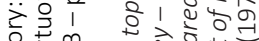

o

ब.

$\frac{1}{4} \cdot \frac{0}{x}<\frac{0}{x}<\frac{0}{0}$

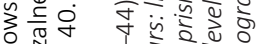

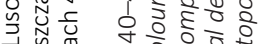

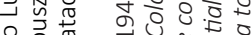

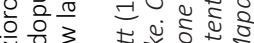

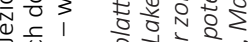

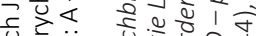

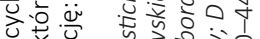

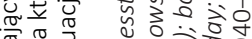

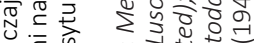

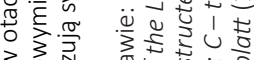

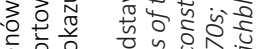

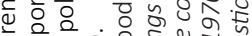

ఖ

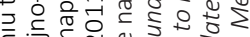

त

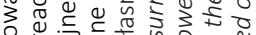

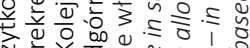

근

ᄀ.

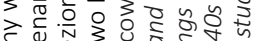

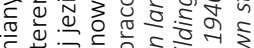

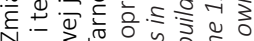

mं है

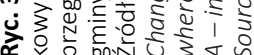




\section{Próba kreowania polityki przestrzennej dla ochrony zasobów w gminie Stęszew}

Ustalenia zawarte w studium gminy Stęszew świadczą o kreowaniu przez samorząd gminny polityki przestrzennej, której jednym z głównych założeń jest ochrona istniejących zasobów przyrodniczych i krajobrazowych oraz ich racjonalne wykorzystanie. Konkretne ustalenia, które wynikają z przyjętego kierunku działania to przede wszystkim zastosowanie narzędzia, jakim jest wyłączenie z zabudowy wszystkich terenów rolniczych, zieleni nieurządzonej oraz obszarów leśnych, a także wyznaczenie „zasięgu strefy cennej przyrodniczo predysponowanej do objęcia nowymi formami ochrony przyrody", co daje możliwość poszerzenia ochrony obszarowej o teren posiadający wybitne walory przyrodniczo-krajobrazowe. O determinacji samorządu gminnego w dążeniu do realnego zabezpieczenia przed degradacją obszarów szczególnie wartościowych świadczy przytoczony poniżej przykład, związany z procesem uchwalania miejscowego planu zagospodarowania przestrzennego dla fragmentów miejscowości Tomice i Mirosławki (Uchwała Nr XIV/113/2011).

W grudniu 2009 r. Rada Miejska Stęszewa przystąpiła do sporządzenia miejscowego planu zagospodarowania przestrzennego obejmującego tereny łąk położonych nad Jeziorem Tomickim i w dolinie Samicy Stęszewskiej. Przygotowywanie planu wynikało z potrzeby ochrony cennych przyrodniczo terenów, które poddawane były rosnącej presji zabudowy. W projekcie planu teren ten miał zostać wyłączony spod zabudowy. Należy dodać, że położony jest on częściowo w granicach obszaru Natura 2000 („Ostoja Rogalińska” PLB300017, „Ostoja Wielkopolska” PLH300010) oraz otuliny Wielkopolskiego Parku Narodowego, a także obejmuje lokalizację pomnika przyrody "Źródełko Żarnowieckie”. Od początku plan wzbudzał protesty właścicieli dwóch działek położonych w jego granicach. Właściciele starali się o wydanie warunków zabudowy i zagospodarowania przestrzennego dla posiadanych przez siebie nieruchomości. W marcu 2011 r. plan został uchwalony (Uchwała Nr XIV/113/2011), ale na mocy rozstrzygnięcia nadzorczego Wojewody Wielkopolskiego uchwała Rady Miejskiej dotycząca mpzp została unieważniona. Jako powód unieważnienia wskazano błędy zawarte w rysunku planu. Uznano również, że obowiązujące dla gminy studium uwarunkowań i kierunków zagospodarowania przestrzennego nie przewiduje wyłączenia spod zabudowy terenów objętych planem, więc tego rodzaju postanowienie nie może być w nim zawarte. Należy podkreślić, że w obowiązującym wówczas studium gminy Stęszew (2010) istniały zapisy dotyczące konieczności ochrony najcenniejszych przyrodniczo terenów gminy (w tym dolin rzecznych) poprzez zastosowanie narzędzia, jakim jest wyłączenie terenów spod zabudowy oraz sformułowanie zalecenia, aby ograniczyć rozpraszanie się zabudowy na terenach otaczających poszczególne wsie. W 2011 r. gmina ponownie podjęła prace nad przygotowaniem i uchwaleniem planu. Dwaj posiadacze działek na opisywanym terenie ponownie wnieśli zastrzeżenia co do planowanego zakazu zabudowy. Jednocześnie grono mieszkańców gminy, głównie wsi Tomice położonej częściowo na terenie objętym planem, wyraziło swoje poparcie dla projektu i zaczęło szukać wsparcia ze strony instytucji oraz stowarzyszeń gotowych włączyć się w działania zmierzające do uchwalenia planu zakazującego zabudowy i przyjęcia go przez Wojewodę. Poszukiwania zaowocowały pozyskaniem poparcia przez Katedrę Ekologii i Ochrony Środowiska oraz Katedrę Terenów Zieleni i Architektury Krajobrazu Uniwersytetu Przyrodniczego w Poznaniu, Polskiego Towarzystwa Ochrony Przyrody Salamandra oraz Wielkopolskiego Parku Narodowego, przy czym wskazywano, że zabudowa spornego terenu spowoduje nie tylko 
utratę wartości przyrodniczych i przerwanie ciągłości systemów ekologicznych, ale też obniżenie walorów wizualnych i wartości społecznej krajobrazu (ograniczenie dostępności, utrata zasobów lokalnych i zmniejszenie potencjału gminy). Plan został ponownie uchwalony w marcu 2012 r. i ponownie zaskarżony we wrześniu 2012 r. w Wojewódzkim Sądzie Administracyjnym w Poznaniu przez wymienionych wcześniej dwóch właścicieli działek. Uzasadnienie skargi opierało się przede wszystkim na wyrażonym już wcześniej poglądzie, że obowiązujące dla gminy studium nie przewiduje wyłączenia spod zabudowy terenów objętych planem, więc istnieje sprzeczność postanowień zawartych w miejscowym planie zagospodarowania przestrzennego (mpzp) ze studium. Sąd uznał powyższą argumentację za uzasadnioną, uwzględnił skargi i stwierdził nieważność zaskarżonej uchwały. Rada Miejska gminy Stęszew zaskarżyła wyrok WSA w Naczelnym Sądzie Administracyjnym. NSA w 2014 r. uznał, że skarga kasacyjna Rady Gminy zasługuje na uwzględnienie, uchylił zaskarżony wyrok i przekazał sprawę do ponownego rozpoznania WSA w Poznaniu. W uzasadnieniu znalazła się uwaga dotycząca relacji pomiędzy zapisami w studium i mpzp: „Studium nie może mieścić w sobie żadnych zapisów, które można by uznać za konkretne ustalenia planu miejscowego, co byłoby na tym etapie postępowania niedopuszczalne. Zapisy studium nie mogą zatem całkowicie przesądzać o treści planu miejscowego, gdyż wówczas zawierałyby konkretne ustalenia planu miejscowego, a to jest niedopuszczalne. Zapisy studium nie mogą bowiem świadczyć o tym, że rada gminy wykroczyła poza fazę »wstępną" procesu planistycznego. O ile ustalenia mpzp powinny być w miarę szczegółowe, o tyle treść studium powinna być formułowana w sposób bardziej ogólny”. Tak sformułowane uzasadnienie oznacza, że decyzja o wyłączeniu spornego terenu spod zabudowy nie musiała być wcześniej zapisana w studium gminy, aby mogła być później zapisana w planie miejscowym. Poza tym NSA uznał, że jeśli tereny objęte planem nie zostały przewidziane w studium pod zabudowę, „to nie można skutecznie twierdzić, iż wprowadzony w planie miejscowym zakaz zabudowy narusza ustalenia studium" (Wyrok NSA... 2014). Przytoczony przykład świadczy o determinacji władz samorządowych i Rady Gminy Stęszew w dążeniu do uchwalenia planu, który pozwala zachować i wzmocnić ochronę terenów cennych pod względem przyrodniczym i krajobrazowym. Jest dowodem na realną, a nie tylko deklaratywną ochronę tych walorów.

\section{Podsumowanie i wnioski}

Położenie gmin podmiejskich i ich powiązania z miastami są czynnikami determinującymi strategię ich rozwoju. Poddane badaniom trzy podpoznańskie gminy spełniają podstawowe kryteria zapewniające im osiągnięcie sukcesu gospodarczego. W zakresie lokalizacji należą do nich: bliskie sąsiedztwo dynamicznie rozwijającego się centrum aglomeracji, dobra obsługa komunikacyjna, występowanie na ich obszarze cennych i atrakcyjnych zasobów przyrodniczych i kulturowych (Bański 2014).

Polityka przestrzenna tych gmin w znacznym stopniu zorientowana jest na realizację potrzeb ze strony ośrodka miejskiego, jako odbiorcy i konsumenta zasobów i dóbr oferowanych przez wiejską przestrzeń oraz przez krajobraz, będący syntezą elementów przyrodniczych i kulturowych. Zasoby te dostrzegane są jako potencjał rozwojowy i warunek sukcesu gospodarczego gmin, co znajduje wyraz w dokumentach strategicznych i planistycznych. Jednakże sposób korzystania z nich w praktyce gospodarowania przestrzenią 
gmin często wskazuje na brak świadomości (lub ignorowanie) faktu, że są to zasoby ograniczone i nieodnawialne, a także budzi obawy co do trwałości i stabilności struktur przyrodniczych i krajobrazowych. Polityka przestrzenna, której wyznacznikiem jest utrwalanie obecnych procesów urbanizacyjnych, postępująca zmiana użytkowania gruntów rolniczych i traktowanie ich przede wszystkim jako zasobu terenów dla zabudowy, przynosi doraźne korzyści finansowe, ale w ujęciu długoterminowym osłabia lokalny potencjał rozwojowy. Nie są doceniane niematerialne, pozaprodukcyjne walory krajobrazu rolniczego, który oferuje miejskim użytkownikom kontakt z otwartą przestrzenią, rozległe widoki, możliwość doświadczania różnorodności natury oraz poznawania historii i lokalnej tradycji zapisanych w jego formach architektonicznych i przestrzennych. Wsie podmiejskie powinny wykorzystywać swój potencjał, budując alternatywne strategie rozwojowe oparte na ich odrębności w stosunku do przestrzeni miejskiej oraz na specyfice krajobrazowejprzyrodniczej i kulturowej (Kowicki 1997).

Przeprowadzone badania wykazały wyraźne różnice w sposobie prowadzenia polityki przestrzennej poszczególnych gmin w kontekście zachowania posiadanych zasobów. Gmina Dopiewo postrzega swoje szanse rozwoju głównie w wykorzystaniu bliskiego sąsiedztwa miasta i korzystnych uwarunkowań komunikacyjnych, co pociąga za sobą strategię przyciągania nowych mieszkańców i inwestorów (firm deweloperskich) oraz przeznaczania dużych obszarów pod zabudowę mieszkaniową i produkcyjno-magazynową. Krajobraz traktowany jest przede wszystkim jako atrakcyjne otoczenie, podnoszące wartość terenów pod zabudowę, a cenne przyrodniczo obszary jako bariery dla zainwestowania. Deklarowane we wstępnej części studium gminy „zachowanie i podniesienie walorów istniejącego środowiska kulturowego" ma charakter postulatywny i nie znajduje potwierdzenia w dalszych zapisach kierunkowych dotyczących rozwoju przestrzennego. Sformułowania zawarte w studium gminy Tarnowo Podgórne stwarzają szansę na zachowanie oraz właściwe wykorzystanie istniejących zasobów, czego wyrazem są m.in. zalecenia dotyczące ochrony krajobrazu rolniczego czy wprowadzenia zakazu zabudowy na części terenów rolniczej przestrzeni produkcyjnej i zwiększenia lesistości terenu. Tym niemniej, obserwacja zjawisk przestrzennych na obszarze obu gmin, potwierdzona przeprowadzonymi analizami zmian użytkowania w strefach o najwyższych walorach przyrodniczych i krajobrazowych, wskazuje na rozbieżności między deklaracjami a praktyką gospodarowania przestrzenią. Studium gminy Stęszew zakłada znaczne ograniczenie powierzchni nowych terenów zabudowanych, w porównaniu z dwiema pozostałymi gminami. Ma na to wpływ z pewnością występowanie w granicach gminy obszarowych form ochrony przyrody o randze krajowej, ale w studium wyznaczono również przebieg lokalnych korytarzy ekologicznych oraz strefy cenne przyrodniczo, postulowane do objęcia nowymi formami ochrony. Poza zapisami strategicznymi, o świadomości wartości posiadanych zasobów przyrodniczych i krajobrazowych świadczą praktyczne działania władz gminy podjęte dla ochrony cennych terenów poddanych presji inwestycyjnej.

Na podstawie analizy dokumentów planistycznych będących wyrazem założeń polityki przestrzennej, prowadzonej przez gminy oraz wybranych przypadków studialnych, sformułowano następujące wnioski:

- Przyjęta strategia dotycząca prowadzenia polityki krajobrazowej w aglomeracji poznańskiej znalazła odbicie w studiach kierunków i zagospodarowania przestrzennego wszystkich badanych gmin, o czym świadczą zapisy w dokumentach, mówiące o znaczeniu zasobów krajobrazowych dla rozwoju gmin i konieczności ich ochrony. 
- W przypadku Dopiewa i Tarnowa Podgórnego zapisy w studiach dotyczące ochrony zasobów krajobrazowych stanowią w znacznej mierze deklaracje, a nie znajdują zastosowania w sposobie dyspozycji przestrzennej poszczególnych form zagospodarowania terenu oraz $w$ realnych działaniach związanych z prowadzeniem polityki przestrzennej, co potwierdza przeprowadzona analiza zmian w użytkowaniu terenu w sąsiedztwie kompleksu leśnego i jeziora, uznanych przez gminy za cenne zasoby.

- Praktyka prowadzenia polityki przestrzennej w gminie Stęszew jest w większym stopniu zgodna z deklaracjami dotyczącymi ochrony zasobów krajobrazowych, zawartymi w studium, niż ma to miejsce w przypadku pozostałych gmin. Władze samorządowe Stęszewa umiejętnie posługują się instrumentami planistycznymi w celu osiągnięcia założonych celów, o czym świadczy przytoczony przykład.

Przeanalizowane dokumenty planistyczne nie świadczą o dążeniu gmin do osiągnięcia spójności w zakresie polityki przestrzennej dotyczącej zasobów krajobrazowych. Wnioski z badań prowadzą do szeregu postulatów dotyczących prowadzenia polityki przestrzennej przez gminy w zakresie racjonalnego i zrównoważonego gospodarowania zasobami krajobrazowymi. Wskazują na konieczność podjęcia działań zmierzających do podniesienia zarówno świadomości wartości zasobów krajobrazu rolniczego, jak też świadomości ich zagrożeń na skutek niewłaściwego gospodarowania przestrzenią. Niezbędne jest tworzenie skutecznych metod i narzędzi dla ich zachowania oraz właściwego wykorzystania jako trwałych zasobów rozwoju lokalnego w gminach podmiejskich. Planowanie przestrzenne jest wyposażone w odpowiednie, prawnie umocowane instrumenty, którymi są studia uwarunkowań i kierunków zagospodarowania przestrzennego gmin oraz miejscowe plany zagospodarowania przestrzennego. W praktyce jednak te instrumenty okazują się nieskuteczne lub źle wykorzystywane. Brak wszechstronnego rozpoznania i wieloaspektowej oceny zasobów, deklaratywne, a nawet sprzeczne zapisy w studiach gmin, fragmentaryczność opracowań planistycznych, a także praktyka prowadzenia inwestycji w oparciu o decyzje administracyjne, przyczyniają się do dezintegracji przestrzeni i deformacji krajobrazu (Böhm 2008). Właściwe wykorzystanie zasobów krajobrazowych w strefie podmiejskiej dotyczy kilku aspektów: 1) kreowania polityki przestrzennej poszukiwania równowagi między długoterminową wizją a doraźnymi rozwiązaniami i decyzjami lokalizacyjnymi, 2) wzmacniania świadomości decydentów w zakresie ograniczoności i nieodnawialności zasobów, 3) stosowania spójnych zapisów w dokumentach planistycznych i ich wdrażania w procesie zarządzania zasobami, 4) współpracy na poziomie samorządów lokalnych, niezbędnej dla ochrony struktur krajobrazowych przekraczających granice administracyjne.

\section{Literatura}

Baranowski A., 2002, Koncepcja partnerstwa „miasto-wieś”, [w:] E. Raszeja (red.), Obszary wiejskie - problemy, projekty, wizje, Urząd Marszałkowski Województwa Wielkopolskiego, Poznań, s. 32-44.

Bański J., 2008, Strefa podmiejska - już nie miasto, jeszcze nie wieś, [w:] A. Jezierska-Thöle, L. Kozłowski (red.), Gospodarka przestrzenna w strefie kontinuum miejsko-wiejskiego w Polsce, Wydawnictwo Naukowe UMK, Toruń, s. 29-43. 
Bański J., 2014, Sukces społeczno-gospodarczy w obszarach metropolitalnych - rola współpracy miejsko-wiejskiej, [w:] M. Dej, K. Janas, O. Wolski (red.), Współpraca miejsko-wiejska w Polsce. Uwarunkowania i potencjał, Instytut Rozwoju Miast, Kraków, s. 47-56.

Böhm A., 2008, Skuteczność istniejq̨cych w Polsce instrumentów prawnych, Czasopismo Techniczne, Architektura, 1-A, Wydawnictwo Politechniki Krakowskiej, Kraków, s. 137-146.

Głębocki B., 2008, Zmiany w strukturze własnościowej i użytkowaniu gruntów w Poznaniu i jego strefie podmiejskiej, [w:] T. Kaczmarek, A. Mazgajski (red.), Powiat poznański. Jakość przestrzeni i jakość życia, Bogucki Wydawnictwo Naukowe, Poznań, s. 177-192.

Halamska M., 2006, Polska: nowy ksztatt relacji wieś-miasto, Roczniki Socjologii Wsi, 26, s. 138-162.

Kowicki M., 1997, Wieś przyszłości jako alternatywa osadnicza Miasta, Monografia, 242, Wydawnictwo Politechniki Krakowskiej, Kraków.

Raszeja E., 2006, Quo vadis civitas? - A rus. Przestrzenno-krajobrazowe aspekty procesów suburbanizacji w obszarze metropolitalnym Poznania, Zeszyty Naukowe Politechniki Poznańskiej, 6, Architektura i Urbanistyka, Wydawnictwo Politechniki Poznańskiej, Poznań, s. 49-56.

Raszeja E., 2008, Ochrona krajobrazu kulturowego w teorii i praktyce zarzqdzania przestrzeniq, [w:] K. Zimniewicz (red.), Bariery w zarzadzaniu parkami krajobrazowymi w Polsce, Polskie Towarzystwo Ekonomiczne, Warszawa, s. 49-67.

Raszeja E., Wilkaniec A., dr Mezer E., 2010, Krajobraz i dziedzictwo kulturowe wsi w aglomeracji poznańskiej, Biblioteka Aglomeracji Poznańskiej, 3, Bogucki Wydawnictwo Naukowe, Poznań.

Raszeja E., 2013, Ochrona Krajobrazu w procesie przekształceń obszarów wiejskich, Wydawnictwo Uniwersytetu Przyrodniczego w Poznaniu, Poznań.

Strategia rozwoju aglomeracji poznańskiej - metropolia Poznań 2020, 2011, Centrum Badań Metropolitalnych UAM, Poznań.

Staszewska S., 2012, Przekształcenia urbanistyczne osiedli wiejskich strefy podmiejskiej dużego Miasta, Barometr Regionalny, Analizy i Prognozy, 4, s. 53-68.

Szczepańska M., Wilkaniec A., 2014, Przekształcenia krajobrazu kulturowego wybranych wsi strefy podmiejskiej Poznania, Studia Obszarów Wiejskich, 35, s. 45-60.

Świderski A. 2007, Geoinformacyjne modele prognozowania użytkowania ziemi, Prace Instytutu Geografii Społeczno-Ekonomicznej i Gospodarki Przestrzennej Uniwersytetu im. Adama Mickiewicza w Poznaniu, Poznań.

Wójcik M., 2013, Przemiany społeczno-przestrzenne osiedli wiejskich. Studium przypadku Łódzkiego Obszaru metropolitalnego, Wydawnictwo Uniwersytetu Łódzkiego, Łódź.

\section{Materiały źródłowe i dokumenty}

Gmina Dopiewo studium uwarunkowań i kierunków zagospodarowania przestrzennego z naniesieniem zmiany studium w formie ujednoliconego tekstu, t. Kierunki, t. Uwarunkowania, zaktualizowane uchwałq Rady Gminy Nr XLIII/308/13 z dnia 25 lutego 2013 r., Wojewódzkie Biuro Planowania Przestrzennego w Poznaniu, Krzysztof Cesar Planowanie Przestrzenne i Drogownictwo w Poznaniu.

Mapa topograficzna w skali 1:25000, 1979, 422.24 Dopiewo, 422.22 Przeźmierowo, zdjęcie topograficzne 1977 r., Główny Urząd Geodezji i Kartografii, Warszawa.

Messtichbtatt, 1940-44, mapy stolikowe w skali 1:25000, założone w latach 1890-92, Dabrowka (sekcja 3666), Buk (sekcja 3665), Sady (sekcja 3556), Gr. Gay (sekcja 3565) http://mapy.amzp. $\mathrm{pl} /$ maps.shtml (dostęp w lutym 2016)

Ortofotomapa, 2014, dostępna online w bibliotekach programu ArcGIS. 
Studium Uwarunkowań i Kierunków Zagospodarowania Przestrzennego Gminy Stęszew 2010, załącznik do uchwały nr XXXIX/370/2010 Rady Miejskiej Gminy Stęszew z dnia 28 września 2010 r.

Studium Uwarunkowań i Kierunków Zagospodarowania Przestrzennego Gminy Stęszew, 2014, załącznik do uchwały nr XXXIX/333/2014 Rady Miejskiej Gminy Stęszew z dnia 11 września 2014 r. Tarnowo Podgórne Studium Uwarunkowań i Kierunków Zagospodarowania Przestrzennego, część A. Analiza w zakresie uwarunkowań zagospodarowania przestrzennego, część B. Kierunki Zagospodarowania przestrzennego, 2011, załącznik do Uchwały Nr XII/134/2011 Rady Gminy Tarnowo Podgórne z dnia 21 czerwca 2011 roku.

Uchwała Nr XIV/113/2011 Rady Miejskiej Gminy Stęszew z dnia 28 grudnia 2011 r. w sprawie: miejscowego planu zagospodarowania przestrzennego dla fragmentów miejscowości Tomice i Mirosławki położonych w obrębach geodezyjnych Tomice, Mirosławki i Rybojedzko, gmina Stęszew.

Wyrok NSA z 2014-11-19, http://www.orzeczenia-nsa.pl/wyrok/ii-osk-1014-13/miejscowy_ plan_zagospodarowania_przestrzennego_skargi_na_uchwaly_rady_gminy_w_przedmiocie_ art_i/2bf5228.html (dostęp w marcu 2016)

\section{Summary}

Natural and landscape resources may provide an important basis for the development of rural communities. Intense urbanization of suburban areas makes them more exposed to rapid loss of these resources than in the case of units located peripherally. In this context, the identification of the existing values in the suburban communes as well as their protection with the use of planning tools seem to be more important. The aim of this study was to identify the level of awareness of landscape resources in the communes of the Poznań agglomeration and confrontation between methods of space management and provisions in municipal spatial policy documents. As an example three communes were selected: Dopiewo, Tarnowo Podgórne and Stęszew - located in the western part of the Poznan County, in the area of intensive development of suburban settlements. The paper focused on the analysis of natural and landscape resources, with particular emphasis on forest areas and water reservoirs. Research was undertaken to recognize changes in the land use model and its dynamics in the vicinity of these areas, which in communes' spatial planning documents are often described as the most valuable from the point of view of existing resources. There were clearly defined differences in the spatial policies of individual communes in the context of the conservation of these resources. 
http://rcin.org.pl 